III. Description of some New and Remarkable Species of Aristolochia from Western Tropical Africa. By Jos. D. Hooker, M.D., F.R.S., V.P.L.S., \&c.

\title{
(Plate XIV.)
}

Read February 16 th, 1865.

1. Aristolochia Goldienna, Hook. f.; glaberrima, foliis ovato- vel triangulari-cordatis basi profunde exsculptis acuminatis, floribus maximis, perianthii refracti utriculo elongato subclavato limbo infundibuliformi campanulato ore ampliato truncato obtuse trilobo lobis caudato-acuminatis, staminibus ad 24, columnæ lobis ad 12 bicruribus.

$H a b$. In Africæ tropicæ occidentalis sylvis ad Eluga a Rev. Episcopo Sierræ Leone detecta (Barter, n. 3427). In insula Fernando Po, Mann, n. 391. In sylvis ad ostium fluminis Old Calabar, Rev. W. C. Thomson.

Frutex scandens, caule 20-pedali, ramulis gracilibus teretibus. Folia longe graciliter petiolata, 6-8-poll. longa, 5-6 lata, basi auriculato-cordata sinu profundo lato fere clauso auriculis rotundatis, acuminata, integerrima vel siccitate crenulata, glaberrima, membranacea, subtus pallida; nervis primariis 7-11, arcuatis, a nervo tenui basim cordatam folii marginante orientibus, gracilibus ; petiolo 6-pollicari. Stipula 0. Perianthium medio refractum; pars inferior vel utriculus in ovario sessilis, 8 poll. longa, $2 \frac{1}{2}-3$ lata, subcylindrica, obtuse 6-costata, apice clavato incurvo, dorso arcuata, subito in limbum perianthii contracta, basi angustata intrusa, intus pilis articulatis mollibus aucta; perianthii pars superior 12 poll. longa, infundibuliformi-campanulata, multicostata, sensim in limbum symmetricum expansa; limbus subinflatus crasse costatus, inter costas lacunosus, ore hiante truncato, obscure trilobo, lobis subito acuminato-caudatis; fauce intus cum lamina circumambiente pendula aucta. Columna subsessilis, $1 \frac{1}{2}$ poll. longa, $\frac{3}{4}$ poll. diametro, intus cava, cavitate infundibuliformi. Antheræ anguste lineares, contiguæ, 1 poll. longæ, columnæ adhærentes. Stigmata erecta, apicibus bifidis incurvis.

Plate XIV. fig. 1 , flower ; 2 , branch and leaves ; 3 , longitudinal section of the throat of the perianth, showing the position and form of the pendulous curtain; 5 , hair from cavity of the utricle; 6, vertical section of the base of the utricle, showing the column; 7 , vertical section of the column; 8 , upper part of anthers and stigma; figs. 3,5, 7, and 8, all magnified.

For the specimen, preserved in alcohol, from which the drawing of this magnificent plant has been made, I am indebted to the Rev. W. C. Thomson, by whom it was found growing in forests near the mouth of the Old Calabar river in 1863, and to whom we are indebted for many interesting plants collected in the same region. At Mr. Thomson's request, it is named after his fellow-labourer, the Rev. Hugh Goldie, of the United Presbyterian Missionary Society.

The most remarkable characters in the structure of $A$. Goldieana are,-1. the number of stamens, which, in all the 160 species hitherto described, are either six or very rarely five, but here amount to about twenty-four, whilst in two other West-African species, VOL. XXV. 
hereafter to be described, they are ten or twelve as in the Malayan genus Thottea, which they further resemble in the 3-lobed perianth, but from which $A$. Goldieana differs in the anthers being sessile, inserted in a single series, and in the 6-celled ovary; 2. the number of styles or divisions of the column, which are about twelve, each bifid, the highest number in described species being six. In habit, size of flower, and colour it resembles the American $A$. gigantea, Mart. \& Zucc., but differs entirely in the form of the perianth and structure of the column.

Another novel point in this flower, but of which more information is wanted, is the swollen and apparently glandular apices of the stigmatic crura. The true position of the stigmatic surfaces is, in other species, marginal and decurrent on the lobes; and if so in this, it is possible that the glands may be secretory organs, whose object may be to attract insects to the column, their agency being obviously essential to fertilization-or, as is the case with the rostellum of some orchids, to aid the transport of pollen by supplying the viscid matter which adheres to the limbs of insects.

The colour of the flower is, according to description, violet, more or less variegated with yellow and red-purple; and the odour, according to the Bishop of Sierra Leone, resembles that of decaying fungi.

2. A. triactina, Hook. f.; glaberrima, foliis coriaceis circumscriptione subhastatooblongis auriculato-trilobis coriaceis basi profunde cordato-bilobis, lobis lateralibus rotundatis sub-2-lobulatis, intermedio oblongo acuminato, perianthii curvati utriculo inflato gibbo, tubo cylindrico, limbo explanato 3-lobo lobis patentissimis caudatoacuminatis, staminibus 10 , lobis columnæ subulatis integris.

Hab. In Africa tropica occidentali ad ostium fluminis Gaboon in Corisco Bay, Mann, n. 1851, Septembri 1862.

Caulis volubilis, 25-pedalis, tenuis, lævis, glaberrimus. Folia petiolata, 2-5 poll. longa, $1 \frac{1}{2}-3$ lata, subcoriacea, superne nitida, lævia, subtus reticulatim nervosa subconcoloria, nervis primariis 3-5 nervulisque prominulis, sinu profundo rotundato aperto vel clauso, lobis lateralibus obtusissimis, subsinuatis; petiolo $\frac{2}{3}-1 \frac{1}{2}$ poll. longo. Stipule 0 . Pedunculi ad 2 poll. longi. Perianthium 2-3 poll. longum, plus minus curvum; utriculus $1-1 \frac{1}{2}$ poll. longus et latus, oblique obovoideus, dorso truncato membranaceus, sub-6-costatus; tubus ad $1 \frac{1}{2}$ poll. longus, fere 1 poll. diametro, teres, ad 12-nervus, ore modice contracto ciliato ; limbus 4 poll. diametro, ad basin trilobus; lobi patentes plani, subæquales, subulato-Janceolati, caudato-acuminati, glaberrimi, marginibus ciliatis. Columna parva, sessilis. Anthere 10. Stigmatis lobi 10, subulati, indivisi (?). Capsula 10-12-pollicaris, 1-1 $\frac{1}{2}$ poll. diametro, 6-costata, costis elevatis, crasse coriacea.

3. A. ManNIr, Hook. f.; foliis breviter petiolatis 5-lobis basi cordato-bilobis subtus nervosis pubescentibus, lobo medio oblongo acuminato, lateralibus brevibus rotundatis, floribus breviter racemosis, perianthii utriculo parvo inflato, tubo curvo sensim dilatato, ore truncato obscure 3-lobo.

Hab. In Africa tropica occidentali ad ostia fluminis Old Calabar, G. Mann, n. 2323, Feb. 1863.

Caulis volubilis, crassiusculus, 10-15-pedalis, teres, glaber. Folia ampla, 6 poll. longa 4-6 lata, dure coriacea, superne glaberrima subnitida, subtus opaca puberula, nervis elevatis creberrime reticulata, 
basi profunde 2-loba, lobis imbricatis, sinu angustissimo clauso, lobo intermedio oblongo vel obovatooblongo abrupte acuminato, 2 lateralibus utrinque valde inæqualibus, inferiore minore rotundato, superiore ascendente oblique oblongo obtuso interdum obscure sinuato vel repando 2-lobo ; nervis

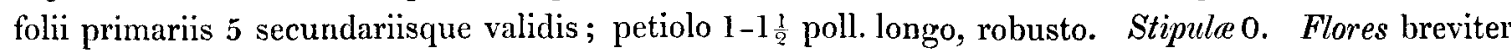
racemosi, rachi $\frac{1}{2}-1$ poll. longo, puberulo; bracteæ parvæ, ovato-subulatæ. Pedunculus cum ovario pollicaris. Perianthium 3 poll. longum, membranaceum, glabrum; utriculus $\frac{1}{3}$ poll. longus, obovoideo-globosus, gibbus, intus lanuginosus; tubus lente curvus, $2 \frac{1}{2}$ poll. Iongus, sensim dilatatus, basi $\frac{1}{3}$ apice $1 \frac{1}{2}$ poll. diametro; ore aperto non ampliato, oblique truncato, obscure 3-lobo, non ciliato, intus fasciculis parvis pilorum obsito. Columna parva stipitata, stipite antheris æquilongo, Anthere 10, lineares. Stigmatis lobi 10, subulati, indivisi (?). 
Trans. Linn . Soc.VoL, XXV, TaB. 14

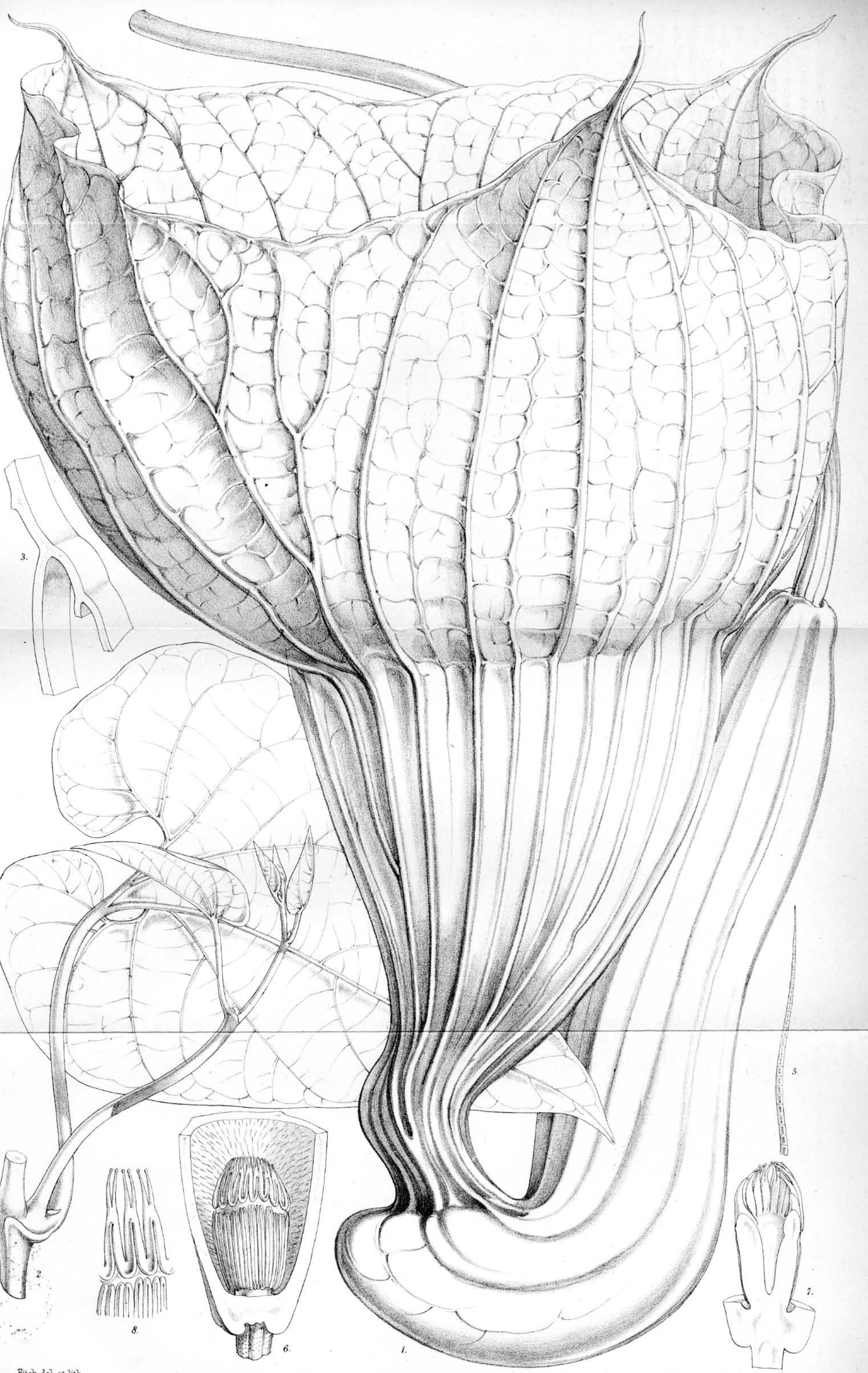

